\title{
Influence of Girdling and Gibberellic Acid on Yield Components, Fruit Composition, and Vestigial Seed Formation of 'Sovereign Coronation' Table Grapes
}

Andrew G. Reynolds and Christiane de Savigny

Cool Climate Oenology and Viticulture Institute, Brock University, St. Catharines, ON L2S 3Al Canada

Additional index words. Seedlessness, growth regulators, Vitis spp., GA

Abstract. Vestigial seeds of 'Sovereign Coronation' table grapes frequently form partial seedcoats that are perceptible during consumption. This problem was addressed through cane/cordon girdling and gibberellic acid $\left(\mathbf{G A}_{3}\right)$ sprays. 'Sovereign Coronation' vines were subjected to one of five treatments [untreated control; cane/cordon girdled; 15 ppm GA at bloom (GA1); GA1 + 40 ppm GA 14 days later (GA2); GA2 + 40 ppm GA 14 days later]. $\mathrm{GA}_{3}$ had no effect on yield or clusters per vine, but postbloom $\mathrm{GA}_{3}$ treatments increased cluster and berry weights and reduced berries per cluster. Fruit maturity was not consistently affected by the treatments, although slight increases in ${ }^{\circ} \mathrm{Brix}$ and $\mathrm{pH}$ and decreases in titratable acidity (TA) were associated with postbloom GA treatments. Use of postbloom $\mathrm{GA}_{3}$ applications reduced the number and weight of vestigial seeds with developed seedcoats, and reduced the number and weight of undeveloped seeds as well in 2 of 3 years. Girdling increased cluster and berry weights, decreased ${ }^{\circ}$ Brix and TA, and increased pH. Transpiration rate of leaves on girdled vines was also higher than control vines on one sampling date. Data suggest that use of bloom and postbloom $\mathrm{GA}_{3}$ applications to 'Sovereign Coronation' may reduce the formation of perceptible vestigial seeds and thus improve the marketability of this cultivar.

Since its release in 1977 (Denby, 1977), the stenospermocarpic seedless grape cultivar Sovereign Coronation (Patricia $\mathrm{x}$ Himrod, Summerland, 1966) has become popular in both Ontario and British Columbia (BC). However, adverse environmental conditions can frequently lead to partial seedcoat formation on the vestigial seeds. Consumers find this feature disconcerting when they are led to believe they are purchasing seedless fruit

Prebloom gibberellic acid $\left(\mathrm{GA}_{3}\right)$ applications to seeded Vitis labruscana Bailey hybrids results in a high percentage of seedless berries (Fukunaga and Kurooka, 1987; Kimura et al., 1996; Tonietto et al., 1983; Ueda and Naito, 1985). The phenomenon is caused by $\mathrm{GA}_{3}$ induced death of the ovule before bloom, after which subsequent $\mathrm{GA}_{3}$ applications enhance berry size through stimulation of cell division (Motomura and Ito, 1972). GA 3 application to seeded $V$. labruscana table grapes such as 'Delaware' has become a standard cultural practice in Japan, and has been mentioned as a possible tool for $V$. vinifera in New Zealand and Australia (Dry and Smart 1986). In Florida, the seedless table grape 'Orlando Seedless' was reported to respond favorably to postbloom GA sprays in terms of reduced seed trace weight and increased berry size (Halbrooks and Crovetti 1989; Halbrooks and Mortensen $1987 ; 1988)$. Trials on 'Sovereign Coronation'

Received for publication 2 Jan. 2003. Accepted for publication 18 June 2003. in $\mathrm{BC}$ with the $\mathrm{GA}_{3}$ product Activol (Zeneca Agrochemicals, Fernhurst, Haslemere, Surrey, U.K.) yielded similarly promising results (Vielvoye, 1992).

There is an expanding market for 'Sovereign Coronation' and other more recentlyintroduced winter-hardy seedless table grape varieties (Reynolds et al., 1997a, 1997b). However, there is concern that adverse environmental conditions (e.g., temperatures $<10$ ${ }^{\circ} \mathrm{C}$, precipitation, or both) at berry set may occasionally lead to full or partial seedcoat formation on vestigial seeds. The purpose of this experiment was to ascertain the efficacy of cane/cordon girdling and $\mathrm{GA}_{3}$ applications on seed trace formation and berry size of 'Sovereign Coronation' table grapes, with the ultimate goal of extending the registration of Activol in Canada to include grapes.

\section{Materials and Methods}

The trial was initiated in June 1998 in a 5-year-old block of 'Sovereign Coronation' at Tregunno Vineyards, Queenston, Ont. Vines were grafted to SO4, spaced $1.5 \mathrm{~m} \times 3.0 \mathrm{~m}$ (vine $\times$ row), and trained to a modified Geneva Double Curtain system (Shaulis et al., 1966) which included a 2.2-m high bilateral cordon containing five-node spurs (upper canopy), plus two additional six-node canes tied horizontally to fruiting wires at each of $1.0-\mathrm{m}$ and $1.5-\mathrm{m}$ heights (lower canopy). The node density at pruning was 15 nodes $/ \mathrm{m}$ for both canopies. The experiment was a randomized complete block with five treatments, six blocks, and five-vine treatment replicates. Each block comprised a partial vineyard row. Treatments were 1) control; 2) girdle (cane girdle year 1; cordon girdle years 2-3); 3) 15 ppm GA at bloom; 4) treatment $3+40$ ppm GA 14 d later; and 5) treatment $4+40$ ppm GA 2 weeks later. Girdling was included as a nonchemical vehicle for possibly increasing berry size and reducing vestigial seeds. Complete girdles were made on the canes and cordons at bloom by girdling pliers. GA was applied in the form of Activol as a dilute spray to runoff using a backpack sprayer (10L; Solo, Newport News, Va.). The same vines were used throughout the trial.

Harvest occurred each year at the discretion of the grower. Data were collected at harvest (7, 10, and 25 Aug. 1998, 1999, and 2000, respectively) for yield components (yield per vine, clusters per vine, cluster weight, berries per cluster, and berry weight). Cluster weigh was calculated from clusters per vine and yield data. A 100-berry sample was collected from each vine and mean berry weight was determined from these samples. Berries per cluster was calculated from cluster weight and berry weight data. An additional 10-berry sample was collected annually from each vine before harvest to determine vestigial seed (seed trace) number and weight. Seed traces were divided into two categories: those with or without partial seedcoat development. Seeds with developed seedcoats were clearly brown in color, whereas those without seedcoats were green and easily discernible strictly on the basis of color from those with seedcoats. Fruit composition $\left[{ }^{\circ}\right.$ Brix, titratable acidity (TA), $\left.\mathrm{pH}\right]$ was measured on 100-berry samples using an Abbé refractometer (AO Corp., Buffalo, N.Y.) manual titration to $\mathrm{pH} 8.30$ endpoint, and $\mathrm{pH}$ meter(Accumet 25; Fisher Scientific, Nepean, Ont.), respectively. Weight of cane prunings (vine size) was measured on each vine with a manual dairy scale immediately after pruning each season.

Roper and Williams (1989) suggested that girdling of 'Thompson Seedless' vines reduced transpiration. To confirm this response under the much cooler and more humid conditions of this trial, transpiration $\left(\mu \mathrm{mol} \cdot \mathrm{cm}^{-2} \cdot \mathrm{s}^{-1}\right.$ of $\left.\mathrm{H}_{2} \mathrm{O}\right)$ was measured hourly on 10 recently-expanded, exposed leaves per treatment replication (control and cordon girdled only) on three dates during Summer 2000 using a steady-state porometer (LI-1600; LI-COR, Lincoln, Nebr.) Leaves were tagged before measurement to ensure that the same leaves were used at each measurement time on each date.

All data were subjected to analysis of variance using the SAS statistical package (SAS Institute, Cary, N.C.). The General Linear Models Procedure was used. Means were separated using Duncan's multiple range test.

\section{Results and Discussion}

Yield components and vine size. Yield was unaffected by girdling or $\mathrm{GA}_{3}$ compared to the control throughout the trial (Table 1). There were also no differences amongst treatments 


\section{GROWTH Regulators}

Table 1. Influence of girdling and gibberellic acid on yield components and vine size of 'Sovereign Coronation' table grapes, Queenston, Ont., 1998-2000.

\begin{tabular}{|c|c|c|c|c|c|c|c|c|c|c|c|c|c|c|c|c|c|c|}
\hline \multirow[b]{2}{*}{ Treatment } & \multicolumn{3}{|c|}{$\begin{array}{c}\text { Yield } \\
\text { (kg per vine) }\end{array}$} & \multicolumn{3}{|c|}{ Clusters/vine } & \multicolumn{3}{|c|}{$\begin{array}{l}\text { Cluster wt } \\
\text { (g) }\end{array}$} & \multicolumn{3}{|c|}{ Berries/cluster } & \multicolumn{3}{|c|}{$\begin{array}{c}\text { Berry wt } \\
(\mathrm{g})\end{array}$} & \multicolumn{3}{|c|}{$\begin{array}{c}\text { Cane prunings wt } \\
\text { (kg/vine) }\end{array}$} \\
\hline & 1998 & 1999 & 2000 & 1998 & 1999 & 2000 & 1998 & 1999 & 2000 & 1998 & 1999 & 2000 & 1998 & 1999 & 2000 & 1998 & 1999 & 2000 \\
\hline Untreated control & 7.2 & 7.4 & $8.4 \mathrm{ab}$ & 60 & 139 & $113 \mathrm{a}$ & $120.2 \mathrm{c}$ & $52.6 \mathrm{~b}$ & $74.1 \mathrm{~b}$ & 45 & $28 \mathrm{a}$ & 31 & $2.61 \mathrm{e}$ & $1.89 \mathrm{e}$ & $2.41 \mathrm{~d}$ & 1.01 & $0.71 \mathrm{bc}$ & 0.43 \\
\hline $\begin{array}{l}\text { at bloom (GA1) } \\
\text { GA1 + } 40 \text { ppm GA }\end{array}$ & 7.3 & 6.9 & $8.4 \mathrm{ab}$ & 60 & 135 & $111 \mathrm{ab}$ & $121.8 \mathrm{c}$ & $52.6 \mathrm{~b}$ & $76.9 \mathrm{~b}$ & 47 & $25 \mathrm{~b}$ & 30 & $2.63 \mathrm{~d}$ & $2.09 \mathrm{~d}$ & $2.53 \mathrm{c}$ & 1.08 & $0.78 \mathrm{a}-\mathrm{c}$ & 0.44 \\
\hline $\begin{array}{l}14 \text { d postbloom } \\
\text { (GA2) } \\
\text { GA2 }+40 \text { ppm GA }\end{array}$ & 8.2 & 7.3 & $8.5 \mathrm{ab}$ & 60 & 126 & $100 \mathrm{ab}$ & $140.2 \mathrm{ab}$ & $59.0 \mathrm{a}$ & $84.6 \mathrm{a}$ & 47 & $26 \mathrm{ab}$ & 30 & $3.07 \mathrm{~b}$ & $2.30 \mathrm{~b}$ & $2.80 \mathrm{a}$ & 1.05 & $0.87 \mathrm{ab}$ & 0.43 \\
\hline $28 \mathrm{~d}$ postbloom & 8.1 & 7.2 & $9.2 \mathrm{a}$ & 57 & 119 & $109 \mathrm{ab}$ & $143.7 \mathrm{a}$ & $60.7 \mathrm{a}$ & $85.7 \mathrm{a}$ & 47 & $25 \mathrm{~b}$ & 31 & $3.10 \mathrm{a}$ & $2.44 \mathrm{a}$ & $2.79 \mathrm{a}$ & 1.1 & $0.93 \mathrm{a}$ & 0.48 \\
\hline Significance & NS & NS & $*$ & NS & NS & $*$ & $* * *$ & $* *$ & $* * *$ & NS & $*$ & NS & $* * *$ & $* * *$ & $* * *$ & NS & $*$ & NS \\
\hline
\end{tabular}

Duncan's multiple range test.

for cluster number in 1998 and 1999, or for berry number and vine size in 1998 and 2000 (Table 1). Berry and cluster weight were the two yield components most affected by $\mathrm{GA}_{3}$ application and girdling. Berry weights were increased over the control by all treatments, but in particular by girdling and by either two or three $\mathrm{GA}_{3}$ applications (Table 1). A substantial increase in berry and cluster weigh occurred in treatments GA2 and GA3 (two and three $\mathrm{GA}_{3}$ applications), as well as the cordon-girdled vines in 1999 (Table 1). There was also a slight decrease in berry number in $\mathrm{GA}_{3}$-treated vines (treatments GA1 and GA3) in 1999 (Table 1).

The girdling and $\mathrm{GA}_{3}$-induced increases in cluster and berry weights of seedless $V$. vinifera table grapes are well documented Weaver and McCune, 1959, 1961; Winkle et al., 1974). Moreover, single applications of $\mathrm{GA}_{3}$ at or around bloom have led to increased berry and cluster weight as a result of berry thinning, but the berry weight increase is less than that induced by later applications (Christodoulou et al., 1968). Use of GA on seedless V. labruscana hybrids has also proven to have similar effects (Shaulis, 1959). Vielvoye (1992) reported that girdling and one or two 40-ppm postbloom $\mathrm{GA}_{3}$ applications increased cluster and berry weights of 'Sovereign Coronation' in a similar experiment in British Columbia, but a single 10-ppm application at bloom had little impact.

A slight increase was also measured in vine size in 1999 in vines treated with GA the previous season (Table 1). Vine size decreased from $1.03 \mathrm{~kg} / \mathrm{vine}$ across all treatments in 1998 to $0.43 \mathrm{~kg} / \mathrm{vine}$ in 2000 , suggesting that the vines may have been overcropped in the final year of the trial. The reason for the reduction in vine size is not known; however, a $28 \%$ higher-than-average rainfall in 2000 (637 mm, compared to an average of $498 \mathrm{~mm}$ ) (Ontario Grape Growers' Marketing Board, 2001) with attendant soil waterlogging, may have been a contributing factor in limiting vegetative growth

Fruit composition. Fruit composition data suggested that the $\mathrm{GA}_{3}$ treatments had either no effect or led to slight delays in fruit maturity in terms of soluble solids ( ${ }^{\circ}$ Brix), with the exception of the GA1 and GA2 treatments in 1999 (Table 2). The single bloom GA application reduced ${ }^{\circ}$ Brix in 1998 , and had no

Table 2. Influence of girdling and gibberellic acid on fruit composition of 'Sovereign Coronation' table grapes, Queenston, Ont., 1998-2000.

\begin{tabular}{|c|c|c|c|c|c|c|c|c|c|}
\hline \multirow[b]{2}{*}{ Treatment } & \multicolumn{3}{|c|}{${ }^{\circ}$ Brix } & \multicolumn{3}{|c|}{ Titratable acidity $(\mathrm{g} / \mathrm{L})$} & \multicolumn{3}{|c|}{$\mathrm{pH}$} \\
\hline & 1998 & 1999 & 2000 & 1998 & 1999 & 2000 & 1998 & 1999 & 2000 \\
\hline Untreated control & $13.3 \mathrm{a}$ & $15.1 \mathrm{c}$ & $14.9 \mathrm{~b}$ & $17.3 \mathrm{a}$ & $15.1 \mathrm{a}$ & $18.0 \mathrm{~b}$ & $2.85 \mathrm{c}$ & $2.89 \mathrm{c}$ & $2.77 \mathrm{~b}$ \\
\hline Cane girdled at bloom & $12.9 \mathrm{c}$ & $14.7 \mathrm{~d}$ & $15.1 \mathrm{a}$ & $16.8 \mathrm{c}$ & $15.1 \mathrm{a}$ & $17.7 \mathrm{bc}$ & $2.87 \mathrm{a}$ & $2.88 \mathrm{c}$ & $2.79 \mathrm{a}$ \\
\hline $10 \mathrm{ppm} \mathrm{GA}_{3}$ at bloom (GA1) & $12.7 \mathrm{~d}$ & $15.3 \mathrm{~b}$ & $14.8 \mathrm{~b}$ & $17.3 \mathrm{a}$ & $15.0 \mathrm{a}$ & $17.8 \mathrm{~b}$ & $2.85 \mathrm{c}$ & $2.91 \mathrm{~b}$ & $2.79 \mathrm{a}$ \\
\hline $\begin{array}{l}\mathrm{GA} 1+40 \text { ppm GA } \\
14 \mathrm{~d} \text { postbloom }(\mathrm{GA} 2) \\
\mathrm{GA} 2+40 \text { ppm GA }\end{array}$ & $13.3 \mathrm{a}$ & $15.4 \mathrm{a}$ & $14.5 \mathrm{c}$ & $16.4 \mathrm{~d}$ & $14.4 \mathrm{~b}$ & $17.4 \mathrm{c}$ & $2.87 \mathrm{a}$ & $2.89 \mathrm{c}$ & $2.78 \mathrm{~b}$ \\
\hline $\begin{array}{l}28 \mathrm{~d} \text { postbloom } \\
\text { Significance }\end{array}$ & $\begin{array}{c}13.1 \mathrm{~b} \\
* * *\end{array}$ & $\begin{array}{c}15.1 \mathrm{c} \\
* * * *\end{array}$ & $\begin{array}{l}14.4 \mathrm{c} \\
* * *\end{array}$ & $\begin{array}{c}17.1 \mathrm{~b} \\
* * * *\end{array}$ & $\begin{array}{c}14.1 \mathrm{~b} \\
* * * *\end{array}$ & $\begin{array}{c}18.4 \mathrm{a} \\
* * *\end{array}$ & $\begin{array}{c}2.86 \mathrm{~b} \\
* * * *\end{array}$ & $\begin{array}{c}2.93 \mathrm{a} \\
* * *\end{array}$ & $\begin{array}{l}2.79 \mathrm{a} \\
* *\end{array}$ \\
\hline
\end{tabular}

${ }^{* * * * * *}$ Significant at $P \leq 0.01$ or 0.001 , respectively. Means within columns followed by different letters are significant at $P \leq 0.05$, Duncan's multiple range test.

effect on TA in 1998-2000 or on pH in 1998. However, at least one of the two postbloom GA treatments reduced TA and increased $\mathrm{pH}$ each season (Table 2). Girdling reduced ${ }^{\circ}$ Brix in 2 of 3 seasons, decreased TA slightly in 1999, and increased $\mathrm{pH}$ in 1998 (Table 2). Applications of $\mathrm{GA}_{3}$ have been reported to advance fruit maturity (Christodoulou et al., 1968), delay maturity slightly (Christodoulou et al., 1968), or have had no effect (Weaver and McCune, 1961; Weaver et al., 1962), depending upon cultivar and season. Previous work with 'Sovereign Coronation' in BC using similar application timings suggested an enhancement in fruit maturity with both $\mathrm{GA}_{3}$ and girdling (Vielvoye, 1992).

Vestigial seed formation. As with previous experience with stenospermocarpic varieties (Halbrooks and Crovetti, 1989; Halbrooks and Mortensen, 1987; 1988; Vielvoye, 1992), our data suggest that $\mathrm{GA}_{3}$ reduced vestigial seed formation (Fig. 1). Use of postbloom GA applications tended to reduce the number and weight of seeds with developed (brown, hard) seedcoats in 1998 (both GA2 and GA3 treatments; Fig 1 A and B) and 1999 (GA2 only; Fig. $1 \mathrm{C}$ and D) and concomitantly increased the number of undeveloped (green, soft) seeds in 1998(Fig. 1A). In 1999, the treatment involving three $\mathrm{GA}_{3}$ sprays also reduced the number and weight of green seeds (Fig. $1 \mathrm{C}$ and D). However, use of a third GA spray in 1999 did not effectively suppress formation of mature vestigial seeds when compared to a two-spray program (Fig. $1 \mathrm{C}$ and D). In 2000, vestigial seed number and weight were substantially lower than the previous 2 years, and there were no differences relative to the control with respect to both brown and green seed number
Table 3. Transpiration rates $\left(\mu \mathrm{mol} \cdot \mathrm{cm}^{2} \cdot \mathrm{s}^{-1}\right.$ of $\left.\mathrm{H}_{2} \mathrm{O}\right)$ of 'Sovereign Coronation' grapevines, Queenston, Ont., 2000

\begin{tabular}{lccc}
\hline Treatment & 19 July & 26 July & 2 Aug. \\
\hline Untreated control & 15.90 & 6.48 & 8.50 \\
Cordon girdled & 15.73 & 7.63 & 9.96 \\
Significance & NS & NS & $* * *$ \\
\hline
\end{tabular}
respectively.

and weight (Fig. 1 E and F). Girdling had no effect on vestigial seed formation throughout the trial (Fig. 1).

It is also noteworthy that vestigial seed number and weight varied considerably during the 3 years of the trial. In the dry 1998 and 1999 seasons, mean mature seed numbers in control treatments were 1.88 and 1.10 , respectively, but only 0.12 in the much wetter 2000 season (Fig. $1 \mathrm{~A}, \mathrm{C}$, and E). Moreover, mean weights of mature seeds in the control treatments were 24.4, 15.9, and $0.9 \mathrm{mg}$ for 1998 , 1999, and 2000, respectively, suggesting that environmental conditions, in this case lower than average rainfall (Ontario Grape Growers' Marketing Board, 2001), might have played a part in their formation. It is also possible that the high crop loads (yield : vine size ratios) in 2000 (19.8) compared to those in 1998 and 1999 (7.6 and 9.1, respectively) may have reduced vestigial seed formation as well.

Water relations. Two of three sampling days produced no differences between untreated control and girdled vines with respect to leaf transpiration rates (Table 3 ). However, the third sampling date suggested a slightly higher transpiration rate in girdled vines. This is in contrast to prior work (Roper and 
Williams, 1989) and others who have reported decreases in stomatal conductance (hence transpiration) of leaves on girdled vines. The reason for higher stomatal conductance in girdled 'Sovereign Coronation' in this study is unknown.

The results of this experiment suggest that one bloom spray plus two or three postbloom applications of $\mathrm{GA}_{3}$ may be used to reduce the number and weight of vestigial seeds in 'Sovereign Coronation' table grapes. Moreover, use of postbloom $\mathrm{GA}_{3}$ sprays will also increase the probability of higher berry weight and cluster weight than untreated vines. Girdling had no effect on vestigial seed formation in this trial, but it increased cluster weight and berry weight in all three seasons. These cultural practices should provide table grape growers in Canada and the northeast U.S, some competitive advantage in a market dominated by $V$. vinifera cultivars.
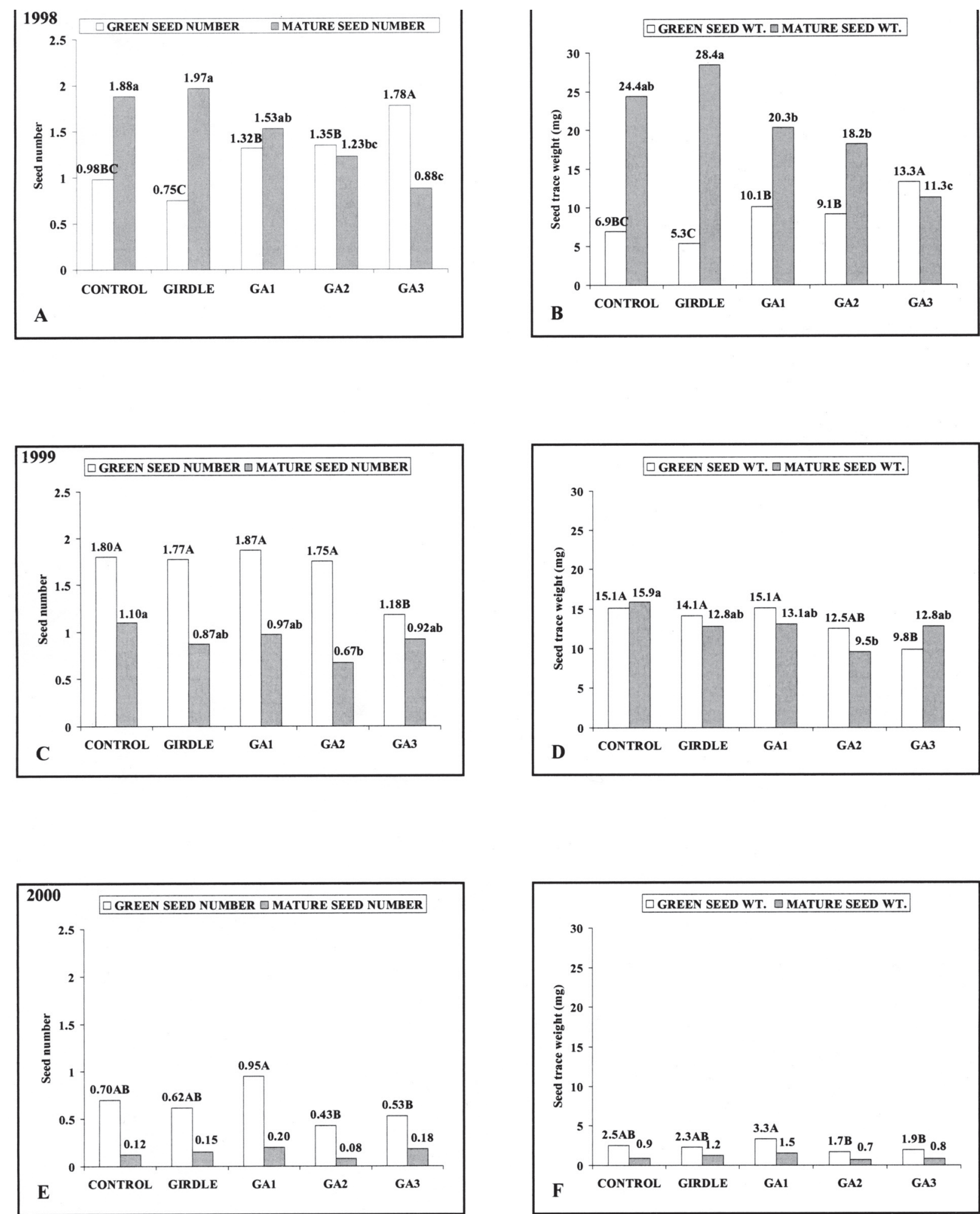

Fig. 1. Influence of girdling and gibberellic acid on vestigial seed formation in berries of 'Sovereign Coronation' table grapes, Queenston, Ont., 1998-2000. Treatment legend: $\mathrm{GA} 1=10 \mathrm{ppm} \mathrm{GA}$ at bloom; GA2= GA1 + 40 ppm GA 14 d. postbloom; GA3 = GA2 + 40 ppm GA $28 \mathrm{~d}$ postbloom. Means followed by different letters are significantly different at $P \leq 0.05$, Duncan's multiple range test. Significant $P$ values for $1998-2000$ were, respectively: $0.0001,0.005$, and 0.021 (green seed number); 0.0001, 0.026, and 0.050 (green seed weight); 0.0001, 0.050, and 0.700 (mature seed number); 0.0001, 0.050, and 0.636 (mature seed weight).

HoRTSCIENCE Vol. 39(3) June 2004 


\section{Literature Cited}

Christodoulou, A.J., R.J. Weaver, and R.M. Pool. 1968. Relation of gibberellin treatment to fruitset, berry development, and cluster compactness in Vitis vinifera grapes. Proc. Amer. Soc. Hort. Sci. 92:301-310

Denby, L.G. 1977. 'Sovereign Coronation' grape. HortScience 12:512.

Dry, P. and R.E. Smart. 1986. How to get rid of the seed in seeded table grapes. Austral. Grapegrower \& Winemaker (Oct.):22.

Fukunaga, S. and H. Kurooka. 1987. Studies on seedlessness of 'Kyoho' grapes induced by gibberellin in combination with streptomycin Bul. Univ. Osaka Prefec. Ser. B 40:1-10.

Halbrooks, M.C. and A.J. Crovetti. 1989. Gibberellic acid increases berry size, reduces seed traces in 'Orlando Seedless' grape. Proc. Plant Growth Reg. Soc. Amer. 16:34-39.

Halbrooks, M.C. and J.A. Mortensen. 1987. Influence of gibberellic acid and various management practices on berry, seed, and cluster development in Orlando Seedless grape. Proc. Fla. State Hort. Soc. 100:312-315

Halbrooks, M.C. and J.A. Mortensen. 1988. Effect of gibberellic acid on berry and seed development in Orlando Seedless grape. HortScience 23:409

Kimura, P.H., G. Okamoto, and K. Hirano. 1996.
Effects of gibberellic acid and streptomycin on pollen germination and ovule and seed development in Muscat Bailey A. Amer. J. Enol. Viticult. 47:152-156.

Motomura, Y. and H. Ito. 1972. Exogenous gibberellin as responsible for the seedless berry development of grapes. II. Role and effect of the prebloom gibberellin application as concerned with the flowering, seedlessness, and seedless berry development of Delaware and Campbell Early grapes. Tohoku J. Agr. Res. 23:15-23.

Ontario Grape Growers' Marketing Board. 2001. Annual report and financial statements for the year ended January $31^{\text {st }}$, 2001. Ont. Grape Growers' Mktg. Board, Vineland Station, Ont

Reynolds, A.G., M.J. Bouthillier, D.A. Wardle, and L.G. Denby. 1997a. 'Skookum Seedless' grape. HortScience 32:743-744.

Reynolds, A.G., M.J. Bouthillier, D.A. Wardle, and L.G. Denby. 1997b. 'Sooke Seedless' grape. HortScience 32:745-746.

Roper, T.R. and L.E. Williams. 1989. Net CO assimilation and carbohydrate partitioning of grapevine leaves in response to trunk girdling and gibberellic acid application. Plant Physiol. 89:1136-1140

Shaulis, N.J. 1959. Gibberellin trials for New York grapes. N.Y. Farm Res. 25:11.

Shaulis, N.J., H. Amberg, and D. Crowe. 1966.
Response of Concord grapes to light, exposure, and Geneva Double Curtain training. Proc. Amer. Soc. Hort. Sci. 89:268-280

Tonietto, J., A. Miele, and P. Silveira Jr. 1983. O acido giberelico no desenvolvimento de bagas sem sementes da uva 'Isabel'. Pesq. Agropec. Bras. 18:381-386.

Ueda, H. and R. Naito. 1985. Relation between the type of flowering and the seedlessness ratio in the GA-treated clusters of 'Muscat Bailey A' grape. J. Jpn. Soc. Hort. Sci. 54:192-200.

Vielvoye, J. 1992. Winemakers anticipate "vintage of the century". B.C. Grape Wine Ind. Nwsltr. 2(6): 1 .

Weaver, R.J., A.N. Kasimatis, and S.B. McCune. 1962. Studies with gibberellin on wine grapes to decrease bunch rot. Amer. J. Enol. Viticult. 13:78-82.

Weaver, R.J. and S.B. McCune. 1959. Effect of gibberellin on seedless Vitis vinifera. Hilgardia 29:247-275.

Weaver, R.J. and S.B. McCune. 1961. Effect of gibberellin on vine behavior and crop production in seeded and seedless Vitis vinifera. Hilgardia 30:425-443.

Winkler, A.J., J.A. Cook, W.M. Kliewer, and L.A. Lider. 1974. General viticulture. Univ. Calif. Press, Berkeley. 